Ks. Krzysztof SORDYL*

\title{
DZIEJE SCHIZMY PRYSCYLIAŃSKIEJ (370-385). DRAMATYCZNA LIKWIDACJA PRYSCYLIANIZMU
}

W artykule przedstawię początek i rozwój schizmy pryscyliańskiej oraz jej dramatyczne konsekwencje dla samego Pryscyliana, jego uczniów i Kościoła starożytnego ${ }^{1}$. Postaram się ukazać nurt heterodoksyjny w doktrynie pryscyliańskiej i niemoralność życia tej wspólnoty, ale również błędy ludzi Kościoła i władzy cesarskiej w rozwiązywaniu kontrowersji pryscyliańskiej.

Pryscylianizm był poważnym problemem dla Kościoła w Hiszpanii w 2. poł. IV w. Schizma pryscyliańska wykracza jednak daleko poza śmierć jej twórcy ${ }^{2}$ oraz jej pierwotną geograficzną lokalizację ${ }^{3}$. Przeanalizowane zostaną pierwsze dwa etapy kontrowersji pryscyliańskiej ${ }^{4}$ ze względu na znaczenie, jakie dla podjętej problematyki miały te wydarzenia, które doprowadziły do procesu i skazania Pryscyliana w Trewirze.

Wykorzystane źródła można podzielić na dwie główne grupy: współczesne Pryscylianowi oraz późniejsze od Pryscyliana. Do pierwszej należą: Traktaty Pryscyliana oraz kanony synodów, natomiast do drugiej grupy należy zaliczyć dzieła Sulpicjusza Sewera (Chronica, Dialogorum libri) oraz Hydacjusza (Chronicon). Ponadto wykorzystałem Codex Theodosianus oraz pisma innych autorów starożytnych, m.in. Hieronima, Augustyna, Ambrożego, Latinusa Pacatusa czy imperatora Maksymusa.

${ }^{*}$ Ks. dr Krzysztof Sordyl - absolwent patrologii w Instytucie Teologii Dogmatycznej na Wydziale Teologicznym Uniwersytetu Papieskiego Jana Pawła II w Krakowie; e-mail: k.sordyl@vp.pl.

${ }^{1}$ Tekst ten został przygotowany na podstawie m.in. materiału badawczego zgromadzonego w przygotowywanej do druku w Wydawnictwie Apostolstwa Modlitwy monografii: K. Sordyl, Pryscylian i pryscylianizm. Teologia, historia, mity. Cytaty z pism Pryscyliana zostały przethumaczone na język polski przez autora artykułu.

${ }^{2}$ Prawdopodobnie około roku 600, lub nieco później, pryscylianizm stracił swą siłę i nie miał większego wpływu na poglądy dotyczące współczesnego Kościoła. W VII wieku być może byli jeszcze nieliczni wieśniacy mieszkający w dolinach Galicji, którzy pamiętali jak ich ojcowie poszukiwali siły i uzdrowienia oraz składali przysięgi przy grobie Pryscyliana na północnym zachodzie Półwyspu Iberyjskiego. Nie stanowili oni problemu dla Kościoła galicyjskiego, co możemy stwierdzić na podstawie nielicznych źródeł z tego okresu.

${ }^{3}$ Ekspansję pryscylianizmu omawiam we wspomnianej w 1. nocie monografii.

${ }^{4}$ Proponuję podział schizmy pryscyliańskiej na trzy etapy: pierwszy od wystąpienia Pryscyliana do synodu w Saragossie (380), drugi od wspomnianego synodu do procesu i skazania Pryscyliana (ok. 385), oraz trzeci od śmierci Pryscyliana do II synodu w Bradze (572). 
1. Początki pryscylianizmu. Pryscylian urodził się około 340 roku. Pochodził ze znakomitej rodziny hiszpańskiej, należącej do wysokiej, prawdopodobnie senatorskiej klasy, osiadłej w Betyce. Jako wykształcony laik, według historycznych źródeł ${ }^{5}$, został wtajemniczony w herezję przez Marka z Memfis i jego uczniów: Agape i Helpidiusza ${ }^{6}$. Współczesne studia pokazują jednak, że osobisty kontakt Pryscyliana z Markiem wydaje się niemożliwy i dlatego odrzucają rzekomych nauczycieli Pryscyliana, traktując ich za wytwór wyobraźni jego przeciwników?

W latach siedemdziesiątych IV wieku $(370-375)^{8}$ rozpoczyna on głoszenie nowej, osobliwej formy chrześcijaństwa w okolicach Kordowy i Meridy. Swoją naukę udaje mu się rozszerzyć na regiony Betyki i Luzytanii w południowej Hiszpanii, aż po Galicję i Akwitanię ${ }^{9}$. Pociąga ludzi przede wszystkim surową ascezą. Otacza go grono kobiet. Pryscylian, według Sulpicjusza Sewera ${ }^{10}$, stworzył religijną społeczność, w skład której wchodzili zarówno duchowni, jak i świeccy. Nauka pryscylian zawierała elementy gnostyckie i manichejskie, charakteryzował ją ponadto ekstatyczny profetyzm, korzystanie z apokryfów oraz organizowanie tajnych zebrań o charakterze sekciarskim.

Pryscylian wzywał chrześcijan do głębszego przeżycia przyrzeczeń chrzcielnych i poszukiwania prawdziwego poznania duchowego. Jego nauka znajduje się przede wszystkim w 11 traktatach zachowanych w kodeksie z Biblioteki Uniwersytetu w Würzburgu ${ }^{11}$. Dostrzec należy wezwanie do radykalizmu, który ma być konsekwencją przyjętego chrztu:

„Bowiem, przed wieloma laty, odnowieni odrodzeniem żywego chrztu i gardząc [35] splamionymi ciemnościami pogańskich dzieł, cali oddaliśmy się Bogu, nauczając, że jeżeli ktoś kochałby bardziej kogoś niż Boga nie mógłby być Jego synem"'12.

${ }^{5}$ Por. Hieronymus, Epistula 5, PL 22, 687; tenże, Commentarius in Isaiam LXIV 4, 5, PL 24, 622 .

${ }^{6}$ Por. Sulpicius Severus, Chronica II 46, 1-2, ed. G. de Senneville-Grave, SCh 441, Paris 1999, 332-334; Idacius Aquae Flaviae, Chronicon 13-16, ed. A. Tranoy, SCh 218, Paris 1974, 108. Nie posiadamy precyzyjnego opisu herezji Marka, Agape i Helpidiusza u Sulpicjusza Sewera, ale odwołanie do Egiptu i Zachodu sugeruje gnostycyzm i manicheizm. Zob. H. Chadwick, Priscillian of Avila. The Occult and the Charismatic in the Early Church, Oxford 1976, 20-23.

${ }^{7}$ Por. Chadwick, Priscillian of Avila, s. 21-22; V. Burrus, The Making of a Heretic: Gender, Authority and the Priscillianist Controversy, Berkeley 1995, 139-140. E.Ch. Babut (Priscillien et le Priscillianisme, Paris 1909, 33-36) utożsamia Agape i Helpidiusza z Euchrocją, która później została stracona wraz ze swoim mężem oraz Pryscylianem w Trewirze.

${ }^{8}$ Taką ogólną datację proponuje M. Simonetti (Priscilliano-Priscillianismo, NDPAC III 43334335). Niektórzy autorzy podają rok 373, inni - rok 370. Por. P. Szczur, Pryscylian, PEF VIII 517; tenże, Pryscylianizm, PEF VIII 519; SWP 338; Chadwick, Priscillian of Avila, s. 8.

${ }^{9}$ Por. Chadwick, Priscillian of Avila, s. 11-12.

${ }^{10}$ Por. Sulpicius Severus, Chronica II 46, 3, SCh 441, 334.

${ }^{11}$ Por. Chadwick, Priscillian of Avila, s. 8.

${ }^{12}$ Priscillianus, Tractatus II. Liber ad Damasum episcopum, ed. G. Schepss, CSEL 18, Pragae - Vindobonae - Lipsiae 1889, 34-35: „Nam cum ante conplures annos uiui lauacri regeneratione re- 
Zwolennicy Pryscyliana wzywani są do intensywnego zgłębiania Biblii13 aby zrozumieć głębię szatana ${ }^{14}$. Dlatego mogą się nauczyć przezwyciężać grawitację przyciągającą ciało i wznieść się ku sprawom duchowym. Wezwanie Pryscyliana jest zatem mocno ascetyczne: małżeństwo i prokreacja są uchybieniami, a człowiek natchniony trwa w celibacie, poświęca się dobrowolnemu ubóstwu, praktykuje wegetarianizm, aby stać się bardziej otwartym na charyzmatyczny dar proroctwa.

Wezwanie to nie było skierowane jedynie do jednostek, ale do wszystkich wiernych, by poświęcili się bezwarunkowo Chrystusowi - ich Bogu. Jednakże, przyjęcie tego wezwania nie było możliwe bez wyciszenia się. Wobec tego Pryscylian zaprosił chrześcijan, aby się do niego przyłączyli, opuścili ruchliwe miasta, i oddalili się w ustronne miejsca na wsiach lub w górach. Przed Objawieniem Pańskim (6 I), przez 3 tygodnie powinni oni przygotować się przez ascetyczne odosobnienie $\mathrm{w}$ górach. Podobnie przed Wielkanocą - dni Wielkiego Postu wzywały do pogłębienia życia duchowego, poprzez oddalenie się od zgiełku miasta i udanie się (jak Pan na pustkowie) do cel klasztornych i domów położonych w rejonach mniej dostępnych, które mogły być poza ich diecezją, poza kontrolą lokalnego biskupa. Tam mogli wysłuchać egzegezy Pisma Świętego wykładanej przez Pryscyliana lub innego świeckiego nauczyciela.

Rozprzestrzenianie się społeczności pryscyliańskiej doprowadziło do reakcji ze strony niektórych biskupów hiszpańskich. Hygin, biskup Kordowy (Corduba) poinformował Hydacjusza, biskupa Meridy (Emerita Augusta) o zagrożeniu dla stabilności hiszpańskiej społeczności chrześcijańskiej. Wymienieni biskupi oraz Itacjusz z Ossobony zaczęli zwalczać Pryscyliana i jego zwolenników.

2. Synod w Saragossie (Caesaraugusta). 4 października 380 roku został zwołany synod w Saragossie ${ }^{15}$, na którym nie byli obecni ani Pryscylian, ani jego zwolennicy:

parati et sordentes [35] saecularium actuum tenebras respuentes totos nos dedissemus deo, legentes quod qui quemquam amplius quam Deum diligeret discipulus eius esse non posset".

${ }^{13}$ Por. tenże, Tractatus I. Liber apologeticus, CSEL 18, 28.

${ }^{14}$ Por. tamże, CSEL 18, 13.

${ }^{15}$ Por. Acta Concili Caesaragustani, PL 84, 315-318; F. Roríguez, Concilio I de Zaragoza. Texto critico, I Concilio Caesaraugustano. MDC aniversario, Zaragoza 1981, 9-25. Nie ma wątpliwości, jak zauważa V. Burrus (The Making of a Heretic, s. 43), że ,akta synodu w Saragossie w całości odzwierciedlają stosunek chrześcijan, którym przeszkadzał wpływ Pryscyliana”. Ale jednocześnie w aktach synodu imię Pryscyliana i jego towarzyszy nie jest wspomniane. Sulpicjusz Sewer (Chronica II 47, 1, SCh 441, 334) jednakże przekazuje informację, że wyrok został sformułowany przeciwko Pryscylianowi, Helpidiuszowi i biskupom Instancjuszowi i Salwianowi pod ich nieobecność. Niemożliwe jest ustalenie czy skazanie Pryscyliana i jego zwolenników było zawarte w zaginionej części akt, czy też Sulpicjusz Sewer wymyśla ten szczegół, żeby podkreślić jeszcze bardziej wrogość wobec pryscylian. Sam Pryscylian potwierdza, że imiennie ani on, ani jego zwolennicy nie byli wymienieni na synodzie w Saragossie. Por. Priscillianus, Tractatus II. Liber ad Damasum episcopum, CSEL 18, 35: „Denique in conuentu episcopali qui Caesaraugustae fuit nemo e nostris reus factus tenetur, nemo accusatus, nemo conuictus, nemo damnatus est, nullum nomini 
„Wówczas wydane zostało przez Hydacjusza jakieś pismo, które poniekąd wykładało dyscyplinę prowadzenia życia. Wtedy, wśród takich okoliczności, żaden z nas nie został pojmany, zwłaszcza na podstawie twojego pisma, mającego duże znaczenie w sprawie przeciw niegodziwcom. W piśmie tym, zgodnie z ewangelicznymi nakazami, poleciłeś, aby niczego nie decydowano wobec nieobecnych i tych, którym nie dano możliwości obrony. My jednakże, choć byliśmy tam nieobecni [..."'16.

$\mathrm{Z}$ akt synodalnych wynika, że głównym problemem biskupów ${ }^{17}$, którzy zebrali się w Saragossie, była kwestia dyscypliny. Zabronili niedozwolonych praktyk, takich jak post w niedziele, opuszczanie nabożeństw w święta oraz spotkań niewiast chrześcijańskich z nieznajomymi mężczyznami ${ }^{18}$. Z drugiej strony, nie było żadnego osądu ani potępienia, jeśli chodzi o doktrynę. Wydaje się, że na tym etapie akta oskarżające Pryscyliana jako prawdziwego heretyka (manichejczyka) ciągle jeszcze były w fazie rozwoju i nie zostały użyte na pierwszym synodzie.

3. Rozwój kontrowersji pryscyliańskiej. Według świadectwa Pryscyliana w Merida, gdzie biskupem był Hydacjusz, wybuchł gwałtowny spór. Był on spowodowany wrogim nastawieniem Hydacjusza do jego grupy i jeszcze się zaognił, gdy Hydacjusz postawił w stan oskarżenia członków duchowieństwa i świeckich w swoim mieście ${ }^{19}$.

Instancjusz i Salwian, dwóch biskupów, którzy byli głównymi zwolennikami Pryscyliana ${ }^{20}$, próbowali doprowadzić do porozumienia udając się do Meridy po to, żeby spotkać się z Hydacjuszem. Ale kiedy zbliżyli się do ko-

nostro uel proposito uel uitae crimen obiectum est, nemo ut euocaretur non dicam necessitatem sed nec sollicitudinem habuit".

${ }^{16}$ Priscillianus, Tractatus II. Liber ad Damasum episcopum, CSEL 18, 35: „Datum nescio quod ab Hydatio ibi commonitorium est quod uelut agendae uitae poneret disciplinam: nemo illic nostrum inter illa repraehensus tua potissimum epistula contra inprobos praevalente, in qua iuxta euangelica iussa praeceperas, ne quid in absentes et inauditos decerneretur. Nos tamen, etsi absentes ibi fuimus”. Por. Sulpicius Severus, Chronica II 47, 1, SCh 441, 334.

${ }^{17}$ Dwunastu biskupów zebrało się w Saragossie (4 X 380): Fidacjusz, który prawdopodobnie przewodniczył synodowi, Delfin z Bordeaux, Eutycjusz, Ampeliusz, Augencjusz, Lucjusz, Itacjusz, którzy później stali się najbardziej zaciekłymi przeciwnikami Pryscyliana; Splendoniusz, Waleriusz, Sympozjusz, Karteriusz i Hydacjusz. Hygin, który jako pierwszy doniósł o działaniach Pryscyliana jako nauczyciela, nie był obecny na synodzie. Por. DS I 292-294; Burrus, The Making of a Heretic, s. 28.

${ }^{18}$ Dla bardziej szczegółowej analizy poglądów sformułowanych w Saragossie zob. Burrus, The Making of a Heretic, s. 30-46; Chadwick, Priscillian of Avila, s. 20-36; R. López Caneda, Prisciliano. Su pensamiento y su problema histórico, Santiago de Compostela 1966, 37 i 71-81.

${ }^{19}$ Por. Priscillianus, Tractatus II. Liber ad Damasum episcopum, CSEL 18, 39. Natura oskarżeń przeciwko Hydacjuszowi nie jest znana. H. Chadwick (Priscillian of Avila, s. 31) przypuszcza, że Hydacjusz prawdopodobnie żył w konkubinacie i miał dziecko.

${ }^{20}$ Ich biskupstwa są nieznane, ale jest prawdopodobne, że były blisko Kordowy. Por. M. Conti, Introduction, w: Priscillian of Avila, The Complete Works, Edited with an Introduction, Translation, and Commentary on the Text by M. Conti, New York 2010, 2. 
ścioła, tłum zwolenników Hydacjusza zaatakował ich i zagrodził im drogę, tak więc byli zmuszeni opuścić Meridę w pośpiechu ${ }^{21}$.

Prawdopodobnie w czasie incydentu w Merida (381) Pryscylian został wyświęcony przez Instancjusza i Salwiana na biskupa Awili22 .

Na tym etapie sporu Hydacjusz zaapelował do cesarza Gracjana i otrzymał od niego polecenie, aby wydać zakaz wstępu do kościołów i miast wszystkim heretykom:

„Tak więc, po wielu i to haniebnych kłótniach - na prośbę Hydacjusza - wymuszono na Gracjanie pisemną odpowiedź, na mocy której rozkazano, ażeby wszyscy heretycy opuścili nie tylko kościoły czy też miasta, lecz ażeby zostali wypędzeni poza granice ziem"23.

Jest wielce prawdopodobne, że „oświadczenie Gracjana upoważniło Hydacjusza, aby wskazał winowajców"24, tak więc mógł oskarżyć Pryscyliana i jego zwolenników o manicheizm i zażądać wygnania ich. Hydacjusz i Itacjusz doprowadzili do wydania przez cesarza Gracjana dekretu (381) banicyjnego na zwolenników Pryscyliana oraz konfiskaty kościołów. W tym samym czasie Hydacjusz zdołał uzyskać także poparcie Ambrożego, biskupa Mediolanu.

4. Podróż pryscylian do Rzymu i Mediolanu. Nie chcąc sprzeciwiać się poleceniu cesarza, Pryscylian, Instancjusz i Salwian zdecydowali się opuścić swoje hiszpańskie biskupstwa i odbyć podróż do Italii z nadzieją na uzyskanie poparcia biskupów Rzymu i Mediolanu, a także prosić imperatora w swojej sprawie $^{25}$.

Po drodze do Rzymu zatrzymali się w Akwitanii, gdzie zdołali zdobyć znaczne poparcie lokalnej ludności, szczególnie w mieście Eauze. Potem przenieśli się do Bordeaux, mając nadzieję, że przyjmie ich tam Delfin ${ }^{26}$, biskup tego miasta. Delfin okazał im wielką niechęć i odmówił spotkania się z nimi. Podczas pobytu w Bordeaux Pryscylian i jego towarzysze nadal starali się uzyskać poparcie chrześcijan, tym razem tego regionu, gdzie zostali gościnnie

${ }^{21}$ Priscillianus, Tractatus II. Liber ad Damasum episcopum, CSEL 18, 49-50. Zobacz także: Burrus, The Making of a Heretic, s. 52-53.

${ }^{22}$ Instancjusz i Salwian udzielają mu święceń biskupich, przyłącza się do niego także Hygin. Por. Sulpicius Severus, Chronica II 47, 2, SCh 441, 336; Chadwick, Priscillian of Avila, s. 33.

${ }^{23}$ Sulpicius Severus, Chronica II 47, 2, SCh 441, 336: „Igitur post multa et foeda certamina Ydacio supplicante elicitur a Gratiano tum imperatore rescriptum, quo universi haeretici excedere non ecclesiis tantum aut urbibus, sed extra omnes terras propelli iubebantur", thum. własne. Heretycy, do których odwołuje się Sulpicjusz Serwer w tym fragmencie są manichejczykami. Por. Burrus, The Making of a Heretic, s. 50-51.

${ }^{24}$ Por. Burrus, The Making of a Heretic, s. 54.

${ }^{25}$ Por. Sulpicius Severus, Chronica II 48, 1, SCh 441, 336; Chadwick, Priscillian of Avila, s. 3642; Burrus, The Making of a Heretic, s. 81-94.

${ }^{26}$ Delfin był jednym z biskupów obecnych na synodzie w Saragossie. 
przyjęci przez bogatą wdowę Euchrocję ${ }^{27}$ w jej willi. Gdy wznowili swoją podróż do Rzymu, Euchrocja zdecydowała się podążać wraz z nimi razem ze swoją córką Prokulą ${ }^{28}$. Z poczuciem krzywdy udali się do Rzymu, nauczając po drodze.

Według Sulpicjusza Serwera, Pryscylian i jego zwolennicy najpierw dotarli do Rzymu, a następnie do Mediolanu ${ }^{29}$. Jednakże uczeni raczej odwracają kolejność tych podróży ${ }^{30}$. Wydaje się, że Virginia Burrus przedstawia najbardziej przekonującą rekonstrukcję tego stadium kontrowersji ${ }^{31}$.

Najpierw dotarli do Mediolanu, gdzie szukali poparcia u Ambrożego. Po tym jak biskup Mediolanu odmówił im pomocy, udali się do Rzymu, gdzie Pryscylian przedstawił list papieżowi Damazemu i poprosił o przesłuchanie przed sądem kościelnym w Rzymie:

„Bogu powierzyliśmy nasze Kościoły, których listy - jako świadectwa ponownego przyjęcia do Kościoła - do ciebie przywieźliśmy, przesłane z podpisem całego ludu i kleru [...] My jednak, biorąc pod uwagę to, że wolimy w sprawie wiary sąd świętych raczej niż sąd świecki, przybyliśmy do Rzymu, niczym innym nie powodowani, jedynie o to prosząc, by na początku ciebie wysłuchać, by milczenie nie zostało poczytane jako obawa przed świadomością (wiedzą), ale w większym stopniu po to przybyliśmy, by poświadczyć, przekazując pismo, przebieg wydarzenia i to, co dla wszystkich jest istotniejsze, wiarę katolicką, w której żyjemy"32.

Papież jednakże odmówił przyjęcia zarówno Pryscyliana jak i jego zwolenników, tak więc przenieśli się z powrotem do Mediolanu, ażeby przedstawić swoją sprawę przed sądem cesarskim.

Kiedy Pryscylian i jego towarzysze przebywali w Mediolanie, zdołali, za pomocą przekupstwa, albo wykorzystując antagonizmy wokół osoby Ambrożego, uzyskać poparcie Macedoniusza, który pełnił urząd magister officiorum na dworze cesarza Gracjana. Nawet jeśli Gracjan początkowo ogłosił nakaz

${ }^{27}$ Zyskują dla swej nauki dwie wpływowe niewiasty Euchrocję i Prokulę, żonę i córkę opiewanego przez Auzoniusza retora Delfidiusza. Por. Ausonius Burdigalensis, Commemoratio Professorum Burdigalensium 5, PL 19, 853.

${ }^{28}$ Według opisu Sulpicjusza Sewera (Chronica II 48, 1-2, SCh 441, 336-338), istniała plotka, że Prokula, córka Euchrocji, została uwiedziona i zgwałcona przez Pryscyliana i dokonała aborcji za pomocą ziół.

${ }^{29}$ Por. tamże II 48, 1, SCh 441, 338.

${ }^{30}$ Por. Babut, Priscillien, s. 153; Chadwick, Priscillian of Avila, s. 40.

${ }^{31}$ Por. Burrus, The Making of a Heretic, s. 84-94.

${ }^{32}$ Priscillianus, Tractatus II. Liber ad Damasum episcopum, CSEL 18, 41: „ecclesias nostras commendauimus Deo, quarum communicatorias ad te epistulas detulimus totius cleri et plebis suscribtione transmissas [...] Nos tamen, non omittentes in causa fidei sanctorum iudicium malle quam saeculi, uenimus Romam, nulli graues, hoc solum desiderantes, ut te primum adiremus, ne taciturnitas metus conscientiae iudicaretur, sed magis libellum tradentes rei gestae ordinem et quod omnibus maius est, fidem catholicam in qua uiuimus panderemus". 
wygnania Pryscyliana i biskupów z jego grupy z ich biskupstw, to Macedoniusz zastąpił go nowym, który zezwalał, aby zostali przywróceni do swoich kościołów $^{33}$. W tym momencie Pryscylian i Instancjusz zdecydowali, żeby wrócić do Hiszpanii ${ }^{34}$. Zatem dzięki przekupstwu uzyskali odwołanie cesarskiego dekretu (382) i powrócili do Hiszpanii, zmuszając swoich prześladowców do ucieczki.

Na tym jednak spór się nie zakończył. W następnych miesiącach po odzyskaniu stolic biskupich Pryscylian i Instancjusz znowu musieli stawić czoła opozycji swoich hiszpańskich braci. Nawet jeśli nie było żadnych informacji na temat działalności Hydacjusza na tym etapie sporu, Sulpicjusz Sewer donosi, jak Itacjusz, który był jednym z biskupów obecnych w Saragossie, będący najwierniejszym sprzymierzeńcem Hydacjusza, uporczywie próbował nie dopuścić dwóch heretyckich biskupów do przywrócenia ich na stolice biskupie.

Kiedy z pomocą prokonsula Wolwencjusza, gubernatora Luzytanii, Pryscylian i jego grupa zdobyli rozkaz zaaresztowania Itacjusza jako perturbator ecclesiarum $^{35}$, Itacjusz zdecydował się jednak opuścić Hiszpanię i schronił się w Galii, w cesarskim mieście Trewir. Tam odwołał się do Brytoniusza, biskupa tego miasta, i Grzegorza, prefekta pretorium. Otrzymał od tego ostatniego list z poleceniem, aby Pryscylian i jego towarzysze pojawili się w Trewirze, by odpowiedzieć za swoje zachowanie i doktrynę ${ }^{36}$. Jednakże Grzegorz nie był w stanie uzyskać poparcia od cesarza Gracjana, który początkowo był wrogo nastawiony do Pryscyliana i jego zwolenników. W konsekwencji Pryscylian, który cieszył się patronatem Macedoniusza, odwołał się do potężnego magister officiorum Gracjana i przeniósł proces do Hiszpanii. W dodatku Itacjusz otrzymał rozkaz stawienia się na procesie pod kuratelą cesarskich oficerów.

Itacjusz postanowił uniknąć aresztowania i pozostał w Trewirze, czekając, jak potoczy się bunt uzurpatora Magnusa Maksymusa w Brytanii. Kiedy w 383 r. Gracjan, który wtedy przygotowywał się do walki z Maksymusem w Galii, został potajemnie zamordowany, Maksymus przejął władzę i wkroczył do Trewiru jako nowy cesarz. Itacjusz mógł natychmiast zainteresować Maksymusa kontrowersjami dotyczącymi Pryscyliana i jego zwolenników, i przedstawić ich w jak najgorszym świetle. W takiej sytuacji nowy cesarz zdecydował się zwołać synod w Bordeaux, na którym powinny się pojawić wszystkie zainteresowane strony ${ }^{37}$.

${ }^{33}$ Por. Sulpicius Severus, Chronica II 48, 2, SCh 441, 338.

${ }^{34}$ Salwian, drugi biskup pryscyliański, zmarł podczas swego pobytu w Mediolanie. Por. Sulpicius Severus, Chronica II 48, 2, SCh 441, 338.

${ }^{35}$ Por. Sulpicius Severus, Chronica II 48, 2, SCh 441, 338.

${ }^{36}$ Por. tamże Chronica II 49, 1, SCh 441, 338; Chadwick, Priscillian of Avila, s. 40-42; Burrus, The Making of a Heretic, s. 93.

${ }^{37}$ Zarówno Itacjusz jak i Hydacjusz byli obecni na tym synodzie. Por. Sulpicius Severus, Chronica II 49, SCh 441, 338-340; Chadwick, Priscillian of Avila, s. 42-44; Burrus, The Making of a Heretic, s. 94. 
5. Proces w Trewirze (Augusta Treverorum). Głównym zarzutem, jaki postawił prefekt Ewodiusz Pryscylianowi, był właśnie zarzut o czary. Od czasu edyktu Dioklecjana czary i manicheizm były ze sobą ściśle powiązane. Niemniej jednak, nie wydaje się, iż bycie manichejczykiem w tym czasie stanowiło samo w sobie poważne zagrożenie dla czyjegoś życia. Manichejczycy ukrywali się ${ }^{38}$, jak zauważa Augustyn, ale aż do czasów Anastazjusza i Justyniana nie byli oni nękani egzekucjami. W świetle prawa z 8 maja 381 r., Teodozjusz odebrał manichejczykom obywatelską zdolność prawną, pozbawiając ich legalnych praw, konfiskując ich własności i zabraniając im zgromadzeń ${ }^{39}$. Natomiast przyszłe prawo z 31 marca 382 r. poszło jeszcze dalej, karząc śmiercią niektóre ekstremalne sekty sympatyzujące z manichejczykami w Azji Mniejszej - enkratytów i akwarian ${ }^{40}$. Zachęcano informatorów, aby donosili na takie właśnie osoby, które potem miały być poddane szczególnym przesłuchaniom. Surowość wobec manichejczyków wydaje się być przejściowa i czysto lokalna $^{41}$. Manichejczycy nie byli lubiani i nie cieszyli się zaufaniem, ogólnie uznawani byli za winnych zbrodni ${ }^{42}$.

Oskarżenia Itacjusza, że Pryscylian był potajemnie manichejczykiem oraz potwierdzony fakt, że wierzył on w wyjątkową rolę kobiet, bezpośrednio prowadziły do wniosku, iż zachowanie takie nie przystoi biskupowi. Stąd prawdopodobnie plotka, że Pryscylian zostawił Prokulę z dzieckiem. Oskarżenia o moralne zepsucie potwierdzały tylko istotne oskarżenie o stosowanie magii, zagrożone karą śmierci. Pryscylian ostatecznie został stracony za czary, a nie za herezję. Piętno herezji manichejskiej sprawiało, iż łatwo było uwierzyć $\mathrm{w}$ tak poważne oskarżenia.

W trakcie przesłuchania sądowego Pryscylian przyznał się do zainteresowań magicznymi studiami, do odbywania nocnych spotkań z rozwiązłymi

${ }^{38}$ Por. Augustinus, Confessiones V 10, 19, PL 32, 715-716: „plures enim eos Roma occultat”. Kara śmierci dla manichejczyków została ustanowiona za rządów cesarza Anastazjusza I (419-518). Jeśli chodzi o represje manichejczyków zob. F. Decret, Aspects du Manichéisme dans l'Afrique romaine, Paris 1970, 331-332.

${ }^{39}$ Por. Codex Theodosianus XVI 5, 7, PL 13, 534A-535A.

${ }^{40}$ Hydroparastatae, Aquarianes - starożytna sekta, która używała do Eucharystii wody zamiast wina. Por. E.A. Livingstone, Aquarians, w: The Concise Oxford Dictionary of the Christian Church, New York 2000, 34.

${ }^{41}$ Por. Codex Theodosianus XVI 5, 9, PL 13, 535B-C. Prawo Teodozjusza z 17 czerwca 389 r. (zob. Codex Theodosianus XVI 5, 18, PL 13, 537C-D), do którego odnosi się synod w Mediolanie (390).

${ }^{42}$ Por. Ambrosius, Epistula 50, 14, PL 16, 1158D-1159A. Manichejczycy łączą świętokradztwo z turpitudo. Augustyn (De moribus II 19-20, PL 32, 1374-1378) opowiada o incydentach niemoralności seksualnej wśród manichejczyków, usiłując (raczej nieprzekonująco) sugerować, że nie należały do wyjątków i były powszechne. Wspomina on jednego z manichejskich urzędników, któremu nie podobało się powszechne wyobrażenie o sekcie jako oddanej orgiom seksualnym. Próbował on, bez powodzenia, utworzyć ascetyczną manichejską komunę w swoim własnym domu. Śledztwo w Kartaginie (relacjonowane przez Augustyna w De haeresibus 46, PL 42, 34-38) odkryło ohydne praktyki erotyczne z dziewczyną o imieniu Margarita, niespełna 12 letnią i ze starszą manichejską zakonnicą. 
kobietami i do odprawiania modłów nago. Zestawienie zarzutów było z pewnością zamierzone, żeby zasugerować, że czynności te, które - jak sądzono - charakteryzowały manichejczyków, odbywały się w tym samym miejscu i czasie. Najbardziej „ortodoksyjne” nocne czuwania zawsze były narażone na sugestie, iż dzieją się tam rzeczy niestosowne. Wigilancjusz ${ }^{43}$ uważał ich za niezwykle niebezpiecznych, biorąc pod uwagę zasady czystości ${ }^{44}$.

Jak już wcześniej zostało powiedziane, oskarżenie o modlenie się nago jest prawdopodobnie związane $\mathrm{z}$ wiarą w magiczną moc nagości. Stąd też obawy synodu w Saragossie dotyczące zwolenników Pryscyliana, którzy chodzą z bosymi stopami. Wydaje się, że ascetyczny ruch w IV w. stanowczo utrzymywał, że modlenie się nago, nawet prywatnie i bez świadków, jest wysoce niestosowne ${ }^{45}$. Palestyńscy rabini z pewnością patrzyli na takie praktyki ze wstrętem $^{46}$. Hieronim drwił z Wigilancjusza, ponieważ kiedyś w czasie trzęsienia ziemi w Betlejem, modlił się on o opiekę, nie przerywając swej modlitwy, aby przyzwoicie się ubrać ${ }^{47}$. Niemniej jednak w kontekście oskarżenia o maleficium, ,nagość” Pryscyliana była bardziej magiczna niż nieprzyzwoita.

Po pierwszym procesie Pryscylian został uwięziony a kwestię wyroku pozostawiono władcy. W międzyczasie Itacjusz czuł głęboki uraz do samego siebie, gdyż oskarżył brata biskupa o przestępstwo zagrożone karą śmierci. Przypuszczalnie sam władca pozwolił mu wycofać się z oskarżenia. Jego wycofanie się na tym ostatnim etapie nastąpiło prawdopodobnie na skutek utraty pewności, co do tej sprawy, biorąc pod uwagę, że niepowodzenie w przeprowadzeniu sprawy o przestępstwo zagrożone karą śmierci, łączyło się z ryzy-

${ }^{43}$ Na temat poglądów Wigilancjusza zob. The Oxford Dictionary of the Christian Church, ed. F.L. Cross - E.A. Livingstone, Oxford 2005, 1697; E. Stanula, Wigilancjusz, w: C.V. Manzanares, Pisarze wczesnochrześcijańscy I-VII w. Mały słownik, tłum. E. Burska, Warszawa 2001, 187; G.A. Jülicher, Vigilantius, w: New Schaff-Herzog Encyclopedia of Religious Knowledge, XII, Grand Rapids 1950, 183-184.

${ }^{44}$ Por. Hieronymus, Contra Vigilantium 1, PL 23, 339; tenże, Epistula 109, 3, ed. I. Hilberg, CSEL 55, Vindobonae - Lipsiae 1912, 354-355, tłum. J. Czuj (poprawione: M. Ożóg): Hieronim, Listy, III, ŹMT 61, Kraków 2011, 191. Por. Concilium Eliberitanum (ok. 306) can. 35, SCL I, 55: „Aby kobiety nie czuwały na cmentarzach. Zakazuje się kobietom czuwania na cmentarzu, gdyż często pod pretekstem modlitwy popełniane są poważne wykroczenia”. Uważano, że manichejczycy spotykali się na nabożeństwach, na których obnażone kobiety i mężczyźni modlili się razem. Por. Anastasius Sinaita, In Hexaemeron 7, PG 89, 963.

${ }^{45}$ Por. Sulpicius Severus, Dialogorum lib. 3, 14, PL 20, 219C-220C.

${ }^{46}$ Por. Chadwick, Priscillian of Avila, s. 140, nota 3.

${ }^{47}$ Por. Hieronymus, Contra Vigilantium 11, PL 23, 349A: „De Vigilantio historia. Unde et in hac provincia cum subitus terrae motus, noctis medio omnes de somno excitasset; tu prudentissimus, et sapientissimus mortalium nudus orabas, et referebas nobis Adam et Evam de paradiso: et illi quidem apertis oculis erubuerunt, nudos se esse cernentes, et verenda texerunt arborum foliis: tu et tunica et fide nudus, subitoque timore perterritus, et aliquid habens nocturnae crapulae, sanctorum oculis obscenam partem corporis ingerebas, ut tuam indicares prudentiam. Tales habet adversarios Ecclesia: hi duces contra martyrum sanguinem dimicant: hujuscemodi oratores contra apostolos pertonant, immo tam rabidi canes contra Christi latrant discipulos". 
kiem utraty własnego życia ${ }^{48}$. Jednakże jego wycofanie wymagało drugiego przesłuchania. W funkcji oskarżyciela został zastąpiony przez Patrycjusza, adwokata finansowego (fisci patronus). Zainteresowanie skarbu państwa procesem jest podkreślone wzmianką u Sulpicjusza Sewera w dialogu Gallus. Mówi on o tym, że Maksymus pragnął majątku heretyków. Konfiskaty mienia zakrojone na dużą skalę mogłyby pomóc w nadchodzącej wojnie domowej przy przejęciu kontroli nad Italiąa

Maksymus skazał Pryscyliana na śmierć pod zarzutem maleficium - używania czarów, a wraz z nim także dwóch duchownych: Felicyssyma i Armeniusza, jego bogatą przyjaciółkę Euchrocję, wdowę po Delfidiuszu ${ }^{50}$ i Latroniana. Trybuni zostali wysłani do Hiszpanii, żeby przeprowadzić tam kolejną inkwizycję ${ }^{51}$, której skutkiem było ścięcie Asarbiusza i diakona zwanego Aureliuszem. Biskup Instancjusz, którego skazano w Bordeaux, został wygnany razem ze swoimi uczniami Tyberianem, Tertullusem, Potamiuszem i Janem ${ }^{52}$. Wszystkie posiadłości Tyberiana zostały skonfiskowane ${ }^{53}$.

„Ciało Pryscyliana przewieziono do Hiszpanii, gdzie czczony był przez swoich zwolenników jako męczennik" ${ }^{44}$. Trzeba zauważyć, że śmierć Pryscyliana wywołała falę oburzenia w świecie chrześcijańskim ${ }^{55}$ oraz pogańskim ${ }^{56}$. O tragicznej śmierci Pryscyliana informują nas m.in. Sulpicjusz Sewer ${ }^{57}$ oraz cesarz Maksymus ${ }^{58}$.

${ }^{48}$ Por. Ambrosius, Expositio Psalmi 118 8, 25, ed. M. Petschenig - M. Zelzer, CSEL 62, Vindobonae 1999, 165. Według prawa oskarżycielowi nie wolno było wycofać się, nawet gdyby zorientował się, że sprawy źle toczą się dla niego.

${ }^{49}$ Biuro patronus fisci pojawia się kilka razy w Kodeksie Teodozjusza. Por. Chadwick, Priscillian of Avila, s. 144, nota 2. Sulpicjusz Sewer (Dialogorum lib. 3, 11, PL 20, 217C-218C) wspomina o braku funduszy i uważa, że świadczy to o tym, w jak żałosny sposób Maksymus zajął się całą sprawą, albo jak ogromny wpływ mieli na niego biskupi. Według prawa z 8 maja $381 \mathrm{r}$. (Codex Theodosianus XVI 5, 7, PL 13, 534A-535A) własność manichejska mogła być skonfiskowana. Panegiryk Pacatusa (Panegyricus Theodosii, PL 13, 26) na Teodozjusza opisuje konfiskatę Maksymusa.

${ }^{50}$ Por. Hieronymus, De viris illustribus 122, PL 23, 711B: „Latronianus, provinciae Hispaniae, valde eruditus, et in metrico opere veteribus comparandus, caesus est et ipse Treveris cum Priscilliano, Felicissimo, Juliano, Euchrotia, ejusdem factionis auctoribus. Exstant eius ingenii opera, diversis metris edita". Egzekucja Euchrocji jako wdowy po znakomitym mówcy Bordeaux, zwraca uwagę Auzoniusza, a także Latinusa Pacatusa (Panegyricus Theodosii, PL 13, 12).

${ }^{51}$ Por. Sulpicius Severus, Dialogorum lib. 3, 2, PL 20, 212D-213B.

${ }^{52}$ Por. tenże, Chronica II 50, 1 - 51, 1, SCh 441, 340-344; Hieronymus, De viris illustribus 121, PL 23, 750B; Chadwick, Priscillian of Avila, s. 144-146; Burrus, The Making of a Heretic, s. 94-101.

${ }^{53}$ Por. Sulpicius Severus, Chronica II 51, SCh 441, 344-346. Pierwszy z traktatów z Würzburga wspomina oszczerstwo rzucone przez Tyberiana, Asarbiusza i innych.

${ }^{54}$ Szczur, Pryscylian, s. 517.

${ }_{55}^{55}$ Por. Ambrosius, Epistula 24, 12, PL 16, 1139-1140.

${ }^{56}$ Por. Pacatus, Panegyricus Theodosii 29, PL 13, 504 n.

${ }^{57}$ Por. Sulpicius Severus, Dialogorum lib. 3, 11-13, PL 20, 217-219; tenże, Chronica II 46-51, SCh 441, 332-346.

${ }^{58}$ Por. Maximus Imperator, Ad Siricium Papam, PL 13, 592-594. 
Proces w Trewirze został nie tylko potępiony przez Marcina z Tours i Ambrożego, ale także przez papieża Syrycjusza, który napisał oficjalny list do Maksymusa na znak protestu. List zaginął, ale jego zawartość można wydedukować z szerokiej odpowiedzi Maksymusa. W zasadzie jest pewne, że zażalenia Syrycjusza dotyczyły doprowadzenia do procesu biskupa przed sądem świeckim, zamiast przed synodem, i roli, jaką odegrał biskup Itacjusz w oskarżeniu o przestępstwo zagrożone karą śmierci.

\section{THE HISTORY OF PRISCILLIAN SCHISM (370-385). THE DRAMATIC ELIMINATION OF PRISCILLIANISM}

\section{(Summary)}

Priscillianism was a serious problem for the church in Spain from the second half of IV century till the end of VI century. In this article there has been discussed the beginning and the development of Priscillian schism and its dramatic consequences for Priscillian himself, his followers and the ancient church. Heterodox trend in Priscillian doctrine, immorality of this community's life, as well as the errors of the church people and the imperial authority in solving Priscillian controversy have been shown. The first two stages of Priscillian schism have been analysed: the first one starting from Priscillian's speech in the synod in Saragossa (380), and the second one from the above mentioned synod till Priscillian's trial and execution (385). The reasons for Priscilllian's execution and the reaction to his death, both in Christian and pagan world, have been presented.

Słowa klucze: schizma pryscyliańska, synod w Saragossie, podróż pryscylian do Rzymu i Mediolanu, proces w Trewirze, śmierć Pryscyliana i jego uczniów.

Key words: Priscillian schism, synod of Saragossa, Priscillains' journey from Rome to Milan, the trial in Trier, the death of Priscillan and his followers. 
